\title{
Androgen Receptors, Sex Behavior, and Aggression
}

\author{
Rebecca L. Cunningham ${ }^{a}$ Augustus R. Lumia ${ }^{b}$ Marilyn Y. McGinnis ${ }^{b}$ \\ ${ }^{a}$ Department of Pharmacology and Neuroscience, University of North Texas Health Science Centre at Fort Worth, \\ Fort Worth, Tex., and ${ }^{b}$ Department of Pharmacology, The University of Texas Health Science Centre at San Antonio, \\ San Antonio, Tex., USA
}

\section{Key Words}

Testosterone - Hypothalamic-pituitary-gonadal axis •

Hypothalamic-pituitary-adrenal axis • Estrogen

\begin{abstract}
Androgens are intricately involved in reproductive and aggressive behaviors, but the role of the androgen receptor in mediating these behaviors is less defined. Further, activity of the hypothalamic-pituitary-gonadal axis and hypothalamicpituitary-adrenal axis can influence each other at the level of the androgen receptor. Knowledge of the mechanisms for androgens' effects on behaviors through the androgen receptor will guide future studies in elucidating male reproductive and aggressive behavior repertoires.
\end{abstract}

Copyright $\odot 2012$ S. Karger AG, Basel

\section{Androgen Receptors in Brain}

Androgen receptors (ARs) are highly conserved and are present in organisms ranging from yeast to humans [1]. A vital role of ARs is the neuromodulation of sexual and possibly aggressive behaviors [2]. In this review we will discuss current knowledge of the effects of ARs on sexual and aggressive behaviors. Further, we will examine the role of the hypothalamic-pituitary-adrenal axis
(HPA) on hypothalamic-pituitary-gonadal (HPG) function at the level of the AR.

\section{Androgen Mode of Action}

Androgens are members of the steroid receptor superfamily of transcription factors [3]. Androgens, such as testosterone, act at receptor sites in specific brain areas [4]. The primary mode of action is regulation of gene transcription. Androgens enter the cell, bind to the cytosolic AR, and induce a conformational change that causes the dissociation of heat shock proteins and translocation of the receptor from the cytosol into the nucleus, and finally dimerization of the receptor [5]. The AR dimer binds to a specific DNA sequence, known as the hormone response element, resulting in up- or downregulation of gene transcription [4]. The AR is generally expressed as a single AR, and consists of a N-terminal regulatory domain, DNA-binding domain, small hinge region, and ligand-binding domain [6]. The $\mathrm{N}$-terminal regulatory domain mediates most of AR's transcriptional activity [7].

Androgens can have a second mode of action, which is similar to estrogens having actions that are independent of genomic DNA interactions [8]. Based on rapid actions of testosterone, nongenomic effects of androgens were proposed over 30 years ago [9]. Further, ARs have been localized at extranuclear sites, such as hippocampal dendritic spines [10] and axons of the cerebral cortex [11].

\section{KARGER}

Fax +4161306 1234

E-Mail karger@karger.ch

www.karger.com (c) 2012 S. Karger AG, Basel

0028-3835/12/0962-0131\$38.00/0

Accessible online at:

www.karger.com/nen
Rebecca L. Cunningham

Department of Pharmacology and Neuroscience

University of North Texas Health Science Center at Fort Worth

3500 Camp Bowie Blvd., Fort Worth, TX 76107 (USA)

Tel. +1 817735 5080, E-Mail Rebecca.Cunningham@unthsc.edu 
These extranuclear sites and rapid effects of testosterone indicate the presence of a putative membrane-associated $\mathrm{AR}$ (mAR) [12]. In a further indication that $\mathrm{mAR}$ may be different from $A R, m A R$ is sensitive to $G$ protein-coupled receptor antagonists but not $\mathrm{AR}$ antagonists [flutamide (FLU)] [13, 14]. Functionally, mAR has been associated with increased intracellular calcium [14]. Additionally, chemically modified exogenous androgens that are used clinically and illicitly as performance-enhancing compounds (anabolic androgenic steroids) have significant effects through allosteric modulation of neurotransmitter receptors, such as the GABA-A receptor [122]. Therefore, these data show that AR action may occur in a broader spectrum than previously believed.

\section{Sites of Androgen Action}

Distribution of AR mRNA containing cells has been identified in the forebrain, midbrain, brain stem, and spinal cord $[15,16]$. Further, high concentrations of ARs were present in the medial preoptic area (MPOA), ventromedial hypothalamus (VMH), medial amygdala (AMY), nucleus accumbens, bed nucleus of stria terminalis (BNST), and septum (septum) as demonstrated by AR binding, immunohistochemistry, and in situ hybridization [16-24]. It is notable that the MPOA and the medial AMY have been implicated in the neural control of male sexual behavior [25], whereas the septum, bed nucleus of stria terminalis, and nucleus accumbens are associated with aggression regulation [26-28].

\section{Androgen Receptor Blockade}

The most popular method employed to investigate the effects of ARs on behavior is via antiandrogens. Although many antiandrogens are available, studies on behavior have focused on those that (1) have no detectable androgenic activity, (2) no antigonadotropic activity, and (3) can cross the blood-brain barrier (unless they are implanted intracranially). The most specific and widely used androgen receptor blockers have been FLU, FLU's active metabolite, hydroxyflutamide (OHF), and cyproterone acetate (CA) [29]. CA (1,2 $\alpha$-methylene-6-chloro- $17 \alpha$-acetoxypregna-4,6-diene-3,20-dione) is a steroidal androgen receptor antagonist with weak progestational and glucocorticoid activity [30]. Both FLU and CA do not interfere with $5 \alpha$-dihydrotesterone formation, but rather block androgen binding to the AR [31-33]. In contrast to CA, FLU [a,a,a-trifluoro-2-methyl-4'-nitro-m-propionotoluidide (or 4'-nitro-3'-trifluoromethylisobutyranilide)] is considered a pure antiandrogen, as it is devoid of antigonadotropic [34], progestogenic, estrogenic, and androgenic ac- tivities [34, 35]; however, recent reports have shown that FLU and CA can exert some agonist activity at the level of the AR in neuronal and nonneuronal cells [36-39]. FLU's active metabolite, hydroxyflutamide (OHF; formerly SCH16423: a,a,a-trifluoro-2-methyl-4'-nitro-m-lactotoluidide) $[35,40]$, has been widely used as an antiandrogen as well. OHF has been shown to inhibit cell nuclear AR binding in pooled tissue from the hypothalamus, preoptic area, medial AMY, and septum $[32,41]$.

\section{Sexual Behavior and Androgen Receptors}

Virtually all reproductive-related behaviors, including copulation, aggression, scent marking, and ultrasonic vocalizations, are androgen-dependent [42]. Thus, they are facilitated in the presence of androgens (both endogenous and exogenous) and decline following castration $[21,32]$. However, it appears that separate and perhaps overlapping brain regions mediate different androgendependent behaviors, and even different components of these behaviors.

\section{Studies Using Systemic Antiandrogen Administration}

Antiandrogens have been given systemically to determine if blocking ARs in the entire brain would suppress male sexual behavior. Timing of antiandrogen exposure, with respect to hormonal status, has been shown to be important. In some studies, for example, antiandrogens and testosterone replacement were instituted at the time of castration, while in other studies administration occurred 3 weeks following castration, in which male rats were in an androgen-deficient condition. In testosteronetreated castrated males, administration of both FLU and $\mathrm{OHF}$ at the time of castration was only marginally effective in suppressing male sexual behavior [32]. However, when antiandrogens and testosterone replacement were instituted 3 weeks following castration in androgen-deficient castrated male rats, male sexual behavior was inhibited [32, 41, 43].

The vast majority of studies have focused on the performance aspect or absence of male sexual behavior. However, two important factors to consider are the motivational component of male sexual behavior and reproductive-associated behaviors. In the absence of sexual motivation, copulation is greatly diminished [41]. Restoration of sexual motivation with androgens, as measured by partner preference, can be prevented by FLU [41]. With respect to reproductive-associated behaviors, systemic administration of OHF decreases ultrasonic vocal- 
izations and scent marking [41], but the neural sites involved have yet to be identified. Thus, ARs appear to play a critical role in the expression of sexual behavior, sexual motivation, and reproductive-associated behaviors in rats.

\section{Studies Using Antiandrogen Implants to Localize AR Effects}

The benefit to using intracranial antiandrogen implants is that the entire brain is exposed to testosterone, whereas ARs are blocked only at the site of interest by the intracranial implant. This has proven to be a valuable method for identifying sites of AR action in the brain with regard to specific behaviors, as implanted animals can be tested for their behavioral response in the presence of the blocking agent.

\section{The Medial Preoptic Area}

The MPOA has long been associated with male sexual behavior and has high concentrations of ARs [20-24]. A role for AR activation in the MPOA in mediating male sexual behavior has been examined using intracranial implants. Testosterone implants into the MPOA reinstate male sexual behavior in castrates [44]. Intracranial implants of OHF into the MPOA results in a substantial reduction in mounts, intromissions, and ejaculations in a testosterone-treated castrated male rats [45-47]. Notably, implants of OHF into the MPOA decrease sexual motivation only when placed in the posterior aspect of this brain site [46]. Although far fewer studies have examined sexual motivation, it appears that both sexual performance and sexual motivation are under the control of ARs, though their site specificity may differ. It should be noted that $\mathrm{AR}$ is not the only steroid receptor in the MPOA that mediates male sex behaviors, as the estrogen receptor (ER) also mediates male sex behaviors, possibly relying on ER activation owing to estrogens synthesized locally by aromatase. Interestingly, it has been shown that testosterone can increase aromatase activity, while castration decreases aromatase activity in the MPOA [48]. Further, AR inhibition with FLU can decrease aromatase activity in the MPOA, thus indicating that aromatase activity, and by extension ER activation, may be AR-dependent in the MPOA [48].

Inhibition of testosterone conversion to estrogen by infusion of the aromatase inhibitor fadrozole into the MPOA of gonadally intact male rats decreased sex behaviors [49], and sex behaviors were restored with MPOA implants of estrogen and estrogen-BSA conjugate, suggesting that nongenomic mechanisms mediated estrogen action [50]. Thus, both AR and ER in the MPOA are critical for the expression of male sexual behavior.

\section{AMY and Olfactory Bulbs}

Olfactory bulbs and the AMY are intimately connected and both contain ARs [51]. Removal of the olfactory bulbs drastically decreases male sexual behavior [51]. Moreover, olfactory bulb ablation significantly decreases AR binding in the AMY 1-2 days after surgery [51]. This decrease in AR binding was correlated with a decline in sexual behavior [51]. Implants of OHF into the medial AMY were moderately effective in suppressing male sexual behavior [45], suggesting that AR activation in the AMY may play a secondary role in facilitating male sexual behavior. Alternatively, the AMY may be important in some other, yet to be identified, component of male reproductive behavior.

\section{Septum}

In spite of the relatively high concentration of ARs in the septum $[45,46]$, blocking ARs in this brain area had no effect on either performance or motivational components of male sexual behavior. This suggests that other androgen-dependent behaviors may be mediated by the septum.

\section{Ventromedial Hypothalamus}

Few studies have examined the role of the VMH in male sexual behavior despite its high concentration of ARs. Testosterone implanted into the $\mathrm{VMH}$ did not restore copulation in castrated male rats [44]. This is interesting because OHF placed into the VMH is very effective in blocking male sexual behavior [45]. A later study showed that OHF in the anterodorsal VMH, but not the posteroventral $\mathrm{VMH}$, decreased male sexual behavior [47]. Notably, VMH implants of testosterone were effective in restoring sexual motivation, and OHF in the VMH decreased sexual motivation $[44,45]$. These results suggest a role for the $\mathrm{VMH}$ in modulating sexual motivation.

\section{Testosterone and Estrogen}

A number of years ago, a large body of evidence emerged suggesting that the male sex hormone was estrogen and not testosterone. This was referred to as the aromatization hypothesis, as testosterone must be metabolically converted to estradiol via the $\mathrm{P} 450$ aromatase enzyme in the brain to activate male sexual behaviors $[52,53]$. The basis for this hypothesis was (1) very large doses of estrogen restored male sexual behavior [54] and (2) the aromatase inhibitor 1,4,6-androstatriene-3,17-dione (ATD) blocked the effects 
of androgens on male sexual behavior [55]. Later studies demonstrated that physiological doses of estradiol did not restore male sexual behavior, whereas physiological doses of testosterone were very effective [21]. Only testosterone restored ejaculation and increased AR occupation [21]. The nonaromatizable metabolite of testosterone, dihydrotestosterone (DHT), increased AR occupation, but had no effect on male sexual behavior [21]. In one study, the aromatase inhibitor fadrozole was given alone or in combination with testosterone, or with the addition of a very small dose of estradiol [56]. This experiment showed that blocking aromatization did indeed prevent the restoration of male sexual behavior, but not sexual motivation. The combination of testosterone with fadrozole and a very small dose of estradiol restored sexual behavior. However, estradiol alone had no effect on either sexual behavior or sexual motivation [56]. It was concluded that both testosterone and a small amount of estradiol through aromatase are needed to facilitate male sexual behavior.

Animals lacking in functional ARs have been used to study the role of androgen receptor activation in mediating male sexual behavior. The results have been somewhat equivocal, but this may be related to the fact that the defect is present from birth, rather than adulthood. Therefore, one cannot rule out the possibility that the changes in behavior are influenced by early development. In a study on male mice lacking a functional AR gene [57], both male sexual behavior and sexual motivation were low. Testicular feminized (Tfm) mice and rats, which are genetic males with defective ARs, have been used to study the effect of loss of AR function on male sexual behavior. Tfm mice lack functional ARs due to a mutation of the AR gene that results in a shortened AR transcript and no AR protein $[58,59]$. Although these mice lack sensitivity to androgens [60], they still have circulating androgens, such as testosterone [61]. Further, $\mathrm{Tfm}$ mice have a greater AR defect than Tfm rats and also exhibit less male sexual behavior than Tfm rats [1]. Tfm rats show reduced sexual behavior, but not motivation [62]. Both Tfm mice and rats have normal levels of ER binding [1], as well as decreased aromatase activity that is unaffected by testosterone administration [63]. These results suggest that Tfm males have normal ER capacity, but not ER activation due to decreased aromatase activity. This is significant because estrogens have been shown to play a role in male sexual behavior. Consistent with these studies, male sex behaviors were decreased and ER $\alpha$ expression was unaffected in a conditional AR inactivation mouse model that is unaffected by development [64]. The forgoing data are fairly convincing in demonstrating a role for ARs and possibly ER in mediating male reproductive responses. The mechanism by which estrogens contribute to AR action is unknown.

\section{Aggression and Androgen Receptors}

Male aggression is mediated by androgens, and elimination of endogenous androgens by castration abolishes aggression in a variety of species [2]. In spite of the extensive literature demonstrating the critical relationship between androgens and aggression, very little is known about the role of the AR as well as the specific neural sites of AR activity that are either necessary or sufficient to elicit aggression in males. The application of antiandrogens or AR antagonists, CA and FLU, has been used to assess this relationship. The effects of CA on aggression have been studied using animal models. However, the results have been equivocal. For example, the antiandrogen CA reportedly decreased intermale aggression in mice [65] and gerbils [66], whereas in other studies there was no significant effect on aggression [67-69]. Others have reported that male mice given CA did show an initial increase in fight latency, but decreased intermale aggression was evident only after 4 weeks [70]. These authors suggest that extensive exposure to the antiandrogenic blocking agent is necessary to suppress aggression [70]. This contrasts with one other study in which long-term CA treatment was administered to mice exposed to increasing doses of testosterone where no effect on aggression was found [71]. However, based on this finding it is not clear whether the sustained aggression was due to the inability of CA to suppress aggression or whether the increasing testosterone exposure was sufficient to override the inhibitory effect of CA.

The AR antagonist FLU also failed to decrease aggression in castrated male mice given exogenous testosterone [33]. Further, FLU failed to reduce the level of aggression in male castrated mice given the anabolic steroid methyltestosterone [72]. However, FLU did have an inhibitory effect on the ventral prostate, seminal vesicles, and lavator ani weights compared to males given methyltestosterone alone, suggesting FLU differentially affects androgen-sensitive tissue and behavior [72]. The assessment of AR in mediating male aggression was also examined using mice lacking functional androgen receptors (Tfm). Robinson et al. [73] found that Tfm male mice did not display enhanced aggression following administration of various anabolic steroids, indicating that the presence of a functional AR may be necessary for androgens to elicit 
aggressiveness in males. However, the ER has also been reported to mediate aggression in males. Exogenous estrogen administration in castrated Tfm mice and wildtype mice increased aggression [74]. Further, ER $\alpha$ activation is associated with increased aggression, while ER $\beta$ activation is associated with decreased aggression [74, 75]. While these findings implicate both AR and ER in the evocation of aggressive behaviors, both the relative contribution of AR activation and the specific neural sites involved are poorly understood.

\section{HPA System Involvement}

Stress can inhibit sex steroid hormone-dependent physiology and behavior [76-78]. The neuroendocrine system involved in mediating responses to stress is the HPA, which consists of direct influences and feedback interactions between the hypothalamus, pituitary, and adrenal gland [79]. Upon activation of the HPA axis, the paraventricular nucleus of the hypothalamus and the pituitary secrete corticotropin-releasing hormone and adrenocorticotropic hormone, respectively [79]. These hormones act upon the adrenal gland to produce glucocorticoid hormones, such as corticosterone [79]. Through a negative feedback cycle, glucocorticoids can act on receptors in the hypothalamus and pituitary to suppress adrenocorticotropic hormone and corticotropin-releasing hormone secretion [79]. Glucocorticoids can act at two receptors in the brain: mineralocorticoid receptors and the glucocorticoid receptors [80]. These receptors are widely distributed in many brain regions that contain high concentrations of ARs, such as the hypothalamus, hippocampus, cortex, AMY, and septum $[15,16,80]$, indicating the involvement of glucocorticoids in other physiological functions.

Sex Steroid Hormone-Dependent Behaviors and Stress

It is known that HPA activation can inhibit HPG activation, i.e. reproductive physiology and associated behaviors [76-78, 81]. However, HPG activation can also inhibit HPA activation. Brain regions, such as the hypothalamus and AMY, which are activated by stress and express glucocorticoid receptors, can also be activated by sexual experience [80, 82-85]. Studies have shown that prior HPG activation, through aggression or sexual experience can decrease stress reactions [86, 87]. Interestingly, even exogenous manipulation of the HPG axis, via administration of testosterone, can block stress-induced glucocorticoid increase [88]. These studies indicate that the HPA and the HPG systems interact and influence each other.

Androgen Receptors, Sex Behavior, and Aggression

\section{Androgen Receptors and Stress}

This interaction between the HPA and HPG systems could be mediated by AR activation (fig. 1). AR has been shown to be involved in anxiety-related behaviors in rodents $[89,90]$. Studies have shown that AR activation inhibits stress response, while AR inhibition can increase stress response $[89,90]$. Consistent with behavioral studies, mice lacking androgen receptors (ARKO mice) have increased HPA activation, as evidenced by increased corticosterone and adrenocorticotropic hormone release [91]. Even modulation of the HPG system, via AR inhibition, during the perinatal critical period can alter HPA function in adulthood $[92,93]$, indicating that HPG-associated AR activation during the perinatal period is essential for adult HPA function [94].

\section{Testicular Feminization Mutation}

Tfm (testicular feminization mutant) mice are a useful model to study HPG and HPA interactions. Consistent with previous reports that found increased HPA activation in response to pharmacological AR inhibition [89, 90], Tfm mice also display increased HPA activation [95, 96], such as increased anxiety-associated behaviors and corticosterone levels [95]. Interestingly, the locus coeruleus, a brain region implicated in the stress response, contains more neurons and has a larger volume in a Tfm rat model compared to wild-type [97], indicating that the lack of HPG-associated AR activation results in an overactivation of the HPA system. Results from studies using either pharmacological or genetic inhibition of the AR have consistently shown that an AR-mediated mechanism underlies HPA and HPG interactions.

\section{Looking Forward}

In this section of the review we will discuss two unresolved issues related to AR action and sociosexual behaviors: (1) a potential role for the ER in activating male sexual behavior, and (2) the reason for the long lag time for the cessation and restoration of male sexual behavior.

\section{Effects of ER Inhibition}

The permissive role of estrogen in facilitating the display of male sexual behavior is poorly understood. The implication is that estrogen acts via the ER. Further, studies have shown that estrogens, possibly through the ER, can upregulate AR expression both centrally (hypothalamus and AMY) and peripherally (prostate) $[98,99]$. The most powerful evidence for a role of ER in mediating 
Fig. 1. AR control of HPG and HPA axis. Activation of the HPG axis results in increased AR activation, resulting in decreased activation of the HPA axis. Conversely, HPA axis activation decreased AR activation and subsequent HPG activation. HPA and HPG axis can modulate each other at the level of the AR. GnRH = Gonadotropin-releasing hormone; $\mathrm{LH}=$ luteinizing hormone; FSH = follicle-stimulating hormone; $\mathrm{ACTH}=$ adrenocorticotropic hormone; $\mathrm{CRH}=$ corticotropin-releasing hormone.

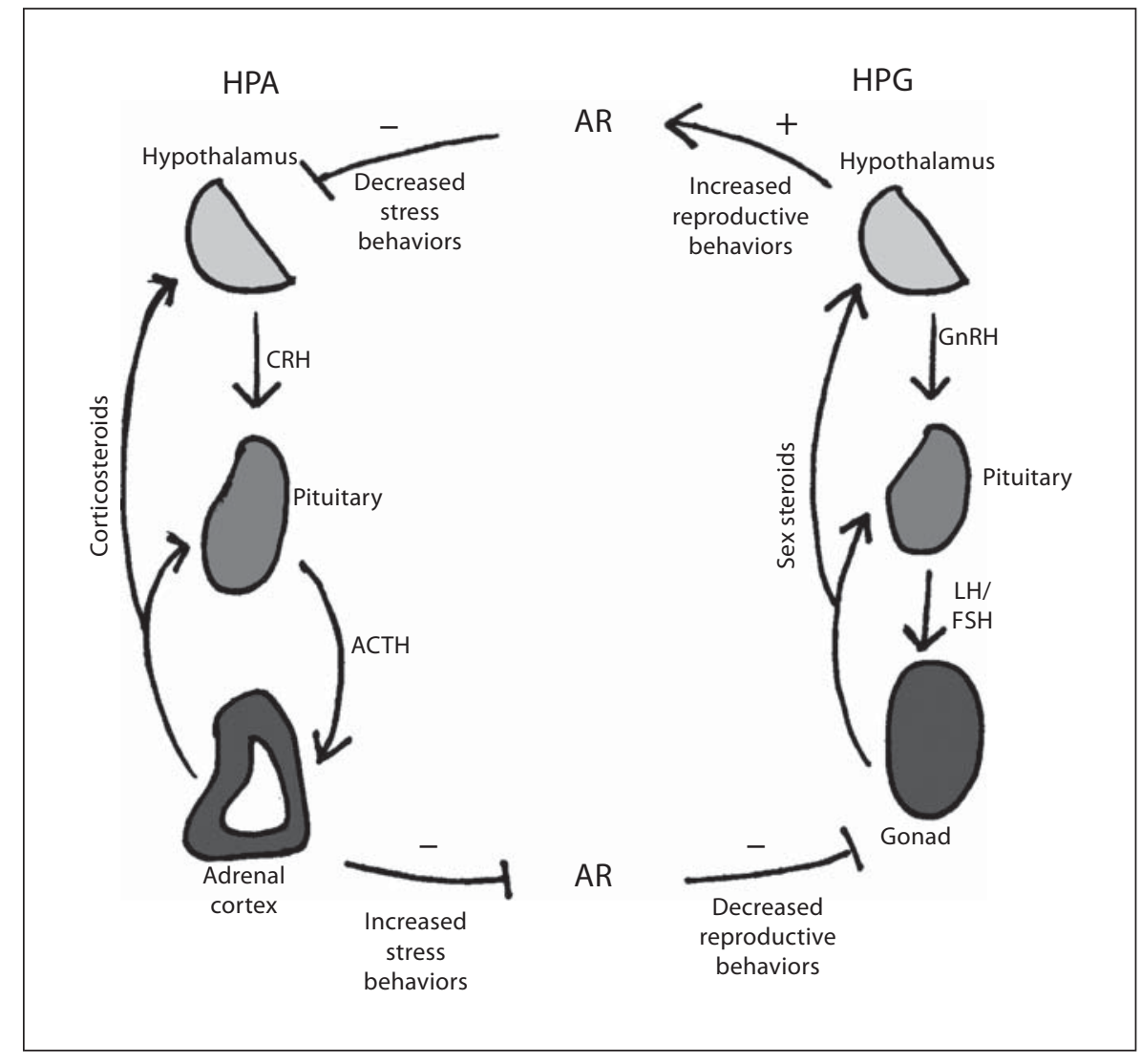

male sexual behavior comes from ER knockout mice [100-102]. In ER $\alpha$ knockout mice, male sexual behavior and aggression were dramatically reduced $[100,101]$. However, sexual motivation remained normal [100-102]. Interestingly, ER $\beta$ knockout mice display normal male sexual behaviors, thus suggesting an ER $\alpha$ - rather than ER $\beta$-mediated mechanism [103]. The problem is that it is impossible to determine if the ER-mediated effects on sexual and aggressive behaviors is due to organizational or activational effects of estrogen acting at the ER, as ER and estrogens are known to play an integral role in the organization of the brain with regard to adult behavioral patterns [1].

The use of ER antagonists has proven to be beneficial to parse out the role of estrogen. Commonly used ER antagonists include: ICI 182,780, CI-628, RU-58668, PHTPP, and MPP. RU-58668 and ICI 182,780 are both pure ER $\alpha$ and ER $\beta$ antagonists with no partial agonist activity [104, 105]. RU-58668 is able to cross the blood-brain barrier [106], unlike ICI 182,770 [107]. The ER antagonist CI-628 can inhibit $\mathrm{ER} \alpha$ and $\mathrm{ER} \beta$, but has partial agonist activity [108]. Lastly, MPP (methyl-pipericlino-pyrazole) is a spe- cific ER $\alpha$ antagonist [109], whereas PHTPP is a selective ER $\beta$ antagonist [110]. In Japanese quails, the ER antagonist CI-628 decreased male sex behaviors and aggression [111-113], but the results are equivocal in rodents with regard to CI-628 [114-116] and RU-58668 [41]. No studies have examined ER antagonism on specific brain nuclei or the role of ER $\alpha$ and ER $\beta$ on male sex behaviors and aggression. Therefore, the question of a role for the ER in facilitating the expression of male sexual behavior remains unanswered.

\section{Proteins}

One of the most intriguing but elusive aspects of male sexual behavior is the reason for the long lag time for the decline of sexual behavior following castration, and the restoration of sexual behavior after hormone replacement therapy. In rats, testosterone levels fall to undetectable levels in less than $24 \mathrm{~h}$ [117]. Thus, the gradual decline of sexual behavior over 2-3 weeks is not due to the presence of testosterone. Following the reinstatement of daily testosterone therapy, the restoration of the full copulatory behavior pattern requires $7-14$ days $[32,55,118]$. 
This is a long time considering that female receptivity can be reinstated within $48 \mathrm{~h}$ [119]. With regard to male sexual behavior, a 'critical exposure' time of approximately $21 \mathrm{~h}$ per day for 7-10 days is needed to restore ejaculation [118]. Neural ARs were significantly decreased within $3 \mathrm{~h}$ of testosterone-capsule removal and was at castration levels by $6 \mathrm{~h}$. This suggests that high levels of AR must be maintained over time to activate male sexual behavior.

It is known that in many species, including humans, prior sexual experience plays a crucial role in maintaining sexual behavior following castration. The more experience, the longer sexual behavior is maintained [120]. One possibility is that proteins induced by androgens are essential for the maintenance of the behavioral response. While this is a plausible mechanism, it has proven extremely difficult to demonstrate the presence of androgen-regulated proteins in brain. In our laboratory, we used various hybridization and PCR techniques to identify four proteins that were upregulated and two proteins that were downregulated by testosterone in the hypothalamus (unpubl. observations). However, we were unable to conclusively demonstrate that these were androgen-regulated gene products. Thus far, no one has been able to definitively link brain proteins to male sex behavior. This problem has plagued researchers for decades and is still unresolved.

\section{Conclusion}

Localization and pharmacological inhibition of ARs have provided overwhelming evidence of AR involvement in male reproductive function and associated behaviors, as well as knowledge of a feedback system involving both the HPA and HPG circuits. However, there is much to be learned and many unknowns of AR action, such as (1) which specific neural sites mediate what specific aspects of reproductive behavior, (2) what is the mechanism of action for estrogen's effects on AR activation, (3) the role of the AR in aggressive behaviors, and (4) the impact on aging on AR action, since testosterone levels decrease with age [121]. The strength of the previous findings on the effects of ARs on reproductive and aggressive behaviors would greatly benefit by addressing these questions.

\section{Acknowledgements}

This work was supported by the following grants: NIH grants 27727 to M.Y.M.; and NIH F32 NS061417, AHA BGIA4180116, and UNTHSC Seed Grant to R.L.C. The authors would like to thank Ms. Kathryn M. Cunningham for her artwork.

\section{References}

1 McGinnis MY, Marcelli M, Lamb DJ: Consequences of mutations in androgen receptor genes: molecular biology and behavior; in Pfaff DW (ed): Hormones, Brain and Behavior. New York, Academic Press, 2002, pp 347-380.

-2 Zuloaga DG, Puts DA, Jordan CL, Breedlove SM: The role of androgen receptors in the masculinization of brain and behavior: what we've learned from the testicular feminization mutation. Horm Behav 2008;53:613626.

3 Tenbaum S, Baniahmad A: Nuclear receptors: structure, function and involvement in disease. Int J Biochem Cell Biol 1997;29: 1325-1341.

4 Mangelsdorf DJ, Evans RM: The RXR heterodimers and orphan receptors. Cell 1995; 83:841-850.

5 Heemers HV, Tindall DJ: Androgen receptor (AR) coregulators: a diversity of functions converging on and regulating the AR transcriptional complex. Endocr Rev 2007;28: 778-808.
-6 Brinkmann AO, Faber PW, van Rooij HC, Kuiper GG, Ris C, Klaassen P, van der Korput JA, Voorhorst MM, van Laar JH, Mulder E, et al: The human androgen receptor: domain structure, genomic organization and regulation of expression. J Steroid Biochem 1989;34:307-310.

7 Simental JA, Sar M, Lane MV, French FS, Wilson EM: Transcriptional activation and nuclear targeting signals of the human androgen receptor. J Biol Chem 1991;266:510-518.

-8 Losel R, Wehling M: Nongenomic actions of steroid hormones. Nat Rev Mol Cell Biol 2003;4:46-55.

-9 Diez A, Sancho MJ, Egana M, Trueba M, Marino A, Macarulla JM: An interaction of testosterone with cell membranes. Horm Metab Res 1984;16:475-477.

10 Tabori NE, Stewart LS, Znamensky V, Romeo RD, Alves SE, McEwen BS, Milner TA: Ultrastructural evidence that androgen receptors are located at extranuclear sites in the rat hippocampal formation. Neuroscience 2005;130:151-163.
11 DonCarlos LL, Sarkey S, Lorenz B, Azcoitia I, Garcia-Ovejero D, Huppenbauer C, Garcia-Segura LM: Novel cellular phenotypes and subcellular sites for androgen action in the forebrain. Neuroscience 2006;138:801807.

12 Su C, Rybalchenko N, Schreihofer DA, Singh M, Abbassi B, Cunningham RL: Cell models for the study of sex steroid hormone neurobiology. J Steroids Hormon Sci 2011, in press.

13 Gatson JW, Singh M: Activation of a membrane-associated androgen receptor promotes cell death in primary cortical astrocytes. Endocrinology 2007;148:2458-2464.

14 Kampa M, Papakonstanti EA, Hatzoglou A, Stathopoulos EN, Stournaras C, Castanas E: The human prostate cancer cell line LNCaP bears functional membrane testosterone receptors that increase PSA secretion and modify actin cytoskeleton. FASEB J 2002;16: 1429-1431.

15 Yu WHA, McGinnis MY: Androgen receptors in cranial nerve motor nuclei of male and female rats. J Neurobiol 2001;46:1-10. 
16 Simerly RB, Chang C, Muramatsu M, Swanson LW: Distribution of androgen and estrogen receptor mRNA-containing cells in the rat brain: an in situ hybridization study. J Comp Neurol 1990;294:76-95.

17 Wood RI, Newman SW: Androgen receptor immunoreactivity in the male and female Syrian hamster brain. J Neurobiol 1999;39: 359-370.

- 18 Lu SF, McKenna SE, Cologer-Clifford A, Nau EA, Simon NG: Androgen receptor in mouse brain: sex differences and similarities in autoregulation. Endocrinology 1998; 139: 1594-1601.

19 Fernandez-Guasti A, Swaab D, RodriguezManzo G: Sexual behavior reduces hypothalamic androgen receptor immunoreactivity. Psychoneuroendocrinology 2003;28:501512.

20 McGinnis MY, Davis PG, Meaney MJ, Singer M, McEwen BS: In vitro measurement of cytosol and cell nuclear androgen receptors in male rat brain and pituitary. Brain Res 1983; 275:75-82.

-21 McGinnis MY, Dreifuss RM: Evidence for a role of testosterone-androgen receptor interactions in mediating masculine sexual behavior in male rats. Endocrinology 1989;124: 618-626.

22 McGinnis MY, Katz SE: Sex differences in cytosolic androgen receptors in gonadectomized male and female rats. J Neuroendocrinol 1996;8:193-197.

$\checkmark 23$ Wood RI, Newman SW: Androgen and estrogen receptors coexist within individual neurons in the brain of the Syrian hamster. Neuroendocrinology 1995;62:487-497.

-24 Roselli CE, Handa RJ, Resko JA: Quantitative distribution of nuclear androgen receptors in microdissected areas of the rat brain. Neuroendocrinology 1989;49:449-453.

25 Hull EM, Dominguez JM: Sexual behavior in male rodents. Horm Behav 2007;52:45-55.

26 Owen K, Peters PJ, Bronson FH: Effects of intracranial implants of testosterone propionate on intermale aggression in the castrated male mouse. Horm Behav 1974;5:8392.

27 Albert DJ, Petrovic DM, Walsh ML, Jonik $\mathrm{RH}$ : Medial accumbens lesions attenuate testosterone-dependent aggression in male rats. Physiol Behav 1989;46:625-631.

28 van Furth WR, Wolterink G, van Ree JM: Regulation of masculine sexual behavior: involvement of brain opioids and dopamine. Brain Res Brain Res Rev 1995;21:162184.

-29 Honer C, Nam K, Fink C, Marshall P, Ksander G, Chatelain RE, Cornell W, Steele R, Schweitzer R, Schumacher C: Glucocorticoid receptor antagonism by cyproterone acetate and RU486. Mol Pharmacol 2003;63 1012-1020.

30 Cyproterone Acetate. Medicines and Healthcare Products Regulatory Authority 2006 $1-42$.
31 Fang S, Liao S: Antagonistic action of antiandrogens on the formation of a specific dihydrotestosterone-receptor protein complex in rat ventral prostate. Mol Pharmacol 1969; 5:428-431.

32 McGinnis MY, Mirth MC: Inhibition of cell nuclear androgen receptor binding and copulation in male rats by an antiandrogen, Sch16423. Neuroendocrinology 1986;43:6368.

33 Clark CR, Nowell NW: The effect of the nonsteroidal antiandrogen flutamide on neural receptor binding of testosterone and intermale aggressive behavior in mice. Psychoneuroendocrinology 1980;5:39-45.

34 Neri R, Florance K, Koziol P, Van Cleave S: A biological profile of a nonsteroidal antiandrogen, SCH 13521 (4'-nitro-3'-trifluoromet hylisobutyranilide). Endocrinology 1972;91: 427-437.

35 Neri RO: Studies on the biological mechanism of action of non-steroidal antiandrogens; in Martini L, Motta M (eds): Androgens and Antiandrogens. New York, Raven Press, 1977, pp 179-190.

36 Nguyen TV, Yao M, Pike CJ: Flutamide and cyproterone acetate exert agonist effects: induction of androgen receptor-dependent neuroprotection. Endocrinology 2007;148: 2936-2943.

37 Kemppainen JA, Wilson EM: Agonist and antagonist activities of hydroxyflutamide and Casodex relate to androgen receptor stabilization. Urology 1996;48:157-163.

38 Lu S, Simon NG, Wang Y, Hu S: Neural androgen receptor regulation: effects of androgen and antiandrogen. J Neurobiol 1999;41: 505-512.

39 Pike CJ: Testosterone attenuates beta-amyloid toxicity in cultured hippocampal neurons. Brain Res 2001;919:160-165.

40 Tucker H, Crook JW: Nonsteroidal antiandrogens. Snythesis and structure-activity relationships of 3 substituted derivatives of 2-hdroxypropionanilides. J Med Chem 1988; 31:954-957.

41 Vagell ME, McGinnis MY: The role of gonadal steroid receptor activation in the restoration of sociosexual behavior in adult male rats. Horm Behav 1998;33:163-179.

42 Rubinow D, Schmidt P: Androgens, brain, and behavior. Am J Psychiatry 1996;153: 974-984.

43 Gladue BA, Clemens LG: Flutamide inhibits testosterone-induced masculine sexual behavior in male and female rats. Endocrinology 1980;106:1917-1922.

44 Harding SM, McGinnis MY: Effects of testosterone in the $\mathrm{VMN}$ on copulation, partner preference, and vocalizations in male rats. Horm Behav 2003;43:327-335.

45 McGinnis MY, Williams GW, Lumia AR: Inhibition of male sex behavior by androgen receptor blockade in preoptic area or hypothalamus, but not amygdala or septum. Physiol Behav 1996;60:783-789.
46 McGinnis MY, Montana RC, Lumia AR: Effects of hydroxyflutamide in the medial preoptic area or lateral septum on reproductive behaviors in male rats. Brain Res Bull 2002. 59:227-234.

47 Harding SM, McGinnis MY: Androgen receptor blockade in the MPOA or VMN: effects on male sociosexual behaviors. Physiol Behav 2004;81:671-680.

48 Roselli CE, Resko JA: Androgens regulate brain aromatase activity in adult male rats through a receptor mechanism. Endocrinology 1984;114:2183-2189.

49 Clancy AN, Zumpe D, Michael RP: Intracerebral infusion of an aromatase inhibitor, sexual behavior and brain estrogen receptorlike immunoreactivity in intact male rats. Neuroendocrinology 1995;61:98-111.

50 Huddleston GG, Paisley JC, Graham S, Grober MS, Clancy AN: Implants of estradiol conjugated to bovine serum albumin in the male rat medial preoptic area promote copulatory behavior. Neuroendocrinology 2007;86:249-259.

-51 Lumia AR, Zebrowski AF, McGinnis MY: Olfactory bulb removal decreases androgen receptor binding in amygdala and hypothalamus and disrupts masculine sexual behavior. Brain Res 1987;404:121-126.

52 Feder H: Perinatal hormones and their role in development of sexually dimorphic behaviors; in Adler N (ed): Neuroendocrinology of Reproduction, New York, Plenum Press, 1981, pp 127-157.

53 Naftolin F, MacLusky N: Aromatization hypothesis revisited; in Serio M (ed): Sexual Differentiation: Basic and Clinical Aspects. New York, Raven Press 1984, pp 79-91.

54 Baum MJ, Vreeburg JT: Copulation in castrated male rats following combined treatment with estradiol and dihydrotestosterone. Science 1973;182:283-285.

55 Kaplan ME, McGinnis MY: Effects of ATD on male sexual behavior and androgen receptor binding: a reexamination of the aromatization hypothesis. Horm Behav 1989; 23:10-26.

56 Vagell ME, McGinnis MY: The role of aromatization in the restoration of male rat reproductive behavior. J Neuroendocrinol 1997;9:415-421.

57 Juntti SA, Tollkuhn J, Wu MV, Fraser EJ, Soderborg T, Tan S, Honda S-I, Harada N, Shah $\mathrm{NM}$ : The androgen receptor governs the execution, but not programming, of male sexual and territorial behaviors. Neuron 2010; 66:260-272.

58 He WW, Kumar MV, Tindall DJ: A frameshift mutation in the androgen receptor gene causes complete androgen insensitivity in the testicular-feminized mouse. Nucleic Acids Res 1991;19:2373-2378. 
-59 Monks DA, Johansen JA, Mo K, Rao P, Eagleson B, Yu Z, Lieberman AP, Breedlove SM, Jordan CL: Overexpression of wild-type androgen receptor in muscle recapitulates polyglutamine disease. Proc Natl Acad Sci USA. 2007;104:18259-18264.

60 Drews U: Direct and mediated effects of testosterone: analysis of sex reversed mosaic mice heterozygous for testicular feminization. Cytogenet Cell Genet 1998;80:68-74.

-61 Jones RD, Pugh PJ, Hall J, Channer KS, Jones TH: Altered circulating hormone levels, endothelial function and vascular reactivity in the testicular feminised mouse. Eur J Endocrinol 2003;148:111-120.

62 Hamson DK, Csupity AS, Ali FM, Watson NV: Partner preference and mount latency are masculinized in androgen insensitive rats. Physiol Behav 2009;98:25-30.

-63 Roselli CE, Salisbury RL, Resko JA: Genetic evidence for androgen-dependent and independent control of aromatase activity in the rat brain. Endocrinology 1987;121:22052210.

-64 Raskin K, de Gendt K, Duittoz A, Liere P, Verhoeven G, Tronche F, Mhaouty-Kodja S: Conditional inactivation of androgen receptor gene in the nervous system: effects on male behavioral and neuroendocrine responses. J Neurosci 2009;29:4461-4470.

65 Nowell NW, Wouters S: Effect of cyproterone acetate upon aggressive behavior in the laboratory mouse. J Endocrinol 1973; 57:R36-R37.

-66 Sayler A: The effect of anti-androgens on aggressive behavior in the gerbil. Physiol Behav 1970;5:667-671.

-67 Brain PF, Evans CM, Poole AE: Studies on the effects of cyproterone acetate administered in adulthood or in early life on subsequent endocrine function and agnostic behavior in male albino laboratory mice. J Endocrinol 1974;61:XLV.

68 Poole AE, Brain PF: Effects of neonatal cyproterone acetate administration on isolation-induced fighting behavior and mounting behavior in male and female TO strain albino mice. Aggress Behav 1975;1:165-176.

69 Clark CR, Nowell NW: Effect of the antiandrogen cyproterone acetate on neural testosterone binding and on intermale aggressive behaviour in male mice. J Endocrinol 1979; 81:137-138.

70 Matte AC, Fabian E: The effect of cyproterone acetate on motor activity, aggression, emotionality, body weight, and testes in wild mice. Andrologia 1978;10:155-162.

-71 Edwards DA: Effects of cyproterone acetate on aggressive behaviour and the seminal vesicles of male mice. J Endocrinol 1970;46:477481.

72 Heilman RD, Brugmans M, Greenslade FC, DaVanzo JP: Resistance of androgen-mediated aggressive behavior in mice to flutamide, an antiandrogen. Psychopharmacology 1976;47:75-80.

Androgen Receptors, Sex Behavior, and Aggression
3 Robinson S, Penatti CA, Clark AS: The role of the androgen receptor in anabolic androgenic steroid-induced aggressive behavior in C57BL/6J and Tfm mice. Horm Behav 2012;61:67-75.

-74 Scordalakes EM, Rissman EF: Aggression and arginine vasopressin immunoreactivity regulation by androgen receptor and estrogen receptor $\alpha$. Genes Brain Behav 2004;3: 20-26.

75 Nomura M, Durbak L, Chan J, Smithies O, Gustafsson J-Ö, Korach KS, Pfaff DW, Ogawa S: Genotype/age interactions on aggressive behavior in gonadally intact estrogen receptor beta knockout (betaERKO) male mice. Horm Behav 2002;41:288-296.

76 Menendez-Patterson A, Florez-Lozano JA, Fernandez S, Marin B: Stress and sexual behavior in male rats. Physiol Behav 1980;24: 403-406.

77 Retana-Marquez S, Bonilla-Jaime $\mathrm{H}$, Vazquez-Palacios G, Martinez-Garcia R, Velazquez-Moctezuma J: Changes in masculine sexual behavior, corticosterone and testosterone in response to acute and chronic stress in male rats. Horm Behav 2003;44: 327-337.

78 Sapolsky RM, Romero LM, Munck AU: How do glucocorticoids influence stress responses? Integrating permissive, suppressive, stimulatory, and preparative actions. Endocr Rev 2000;21:55-89.

79 Gore AC, Roberts JL: Neuroendocrine Systems; in Squire LR, Bloom FE, McConnell SK, Roberts JL, Spitzer NC, Zigmond MJ (eds): Fundamental Neuroscience, ed 2. New York, Academic Press, 2003, pp 1043-1048.

80 Morimoto M, Morita N, Ozawa H, Yokoyama K, Kawata M: Distribution of glucocorticoid receptor immunoreactivity and mRNA in the rat brain: an immunohistochemical and in situ hybridization study. Neurosci Res 1996;26:235-269.

81 Lumley LA, Sipos ML, Charles RC, Charles RF, Meyerhoff JL: Social stress effects on territorial marking and ultrasonic vocalizations in mice. Physiol Behav 1999;67:769775.

82 Coolen LM, Peters HJ, Veening JG: Anatomical interrelationships of the medial preoptic area and other brain regions activated following male sexual behavior: a combined fos and tract-tracing study. J Comp Neurol 1998; 397:421-435.

83 Day HE, Masini CV, Campeau S: The pattern of brain c-fos mRNA induced by a component of fox odor, 2,5-dihydro-2,4,5-trimethylthiazoline (TMT), in rats, suggests both systemic and processive stress characteristics. Brain Res 2004;1025:139-151.

-84 Fendt M, Endres T, Lowry CA, Apfelbach R, McGregor IS: TMT-induced autonomic and behavioral changes and the neural basis of its processing. Neurosci Biobehav Rev 2005;29: 1145-1156.

85 Pfaus JG: Neurobiology of sexual behavior. Curr Opin Neurobiol 1999;9:751-758.
86 De Boer SF, Koolhaas JM: Defensive burying in rodents: ethology, neurobiology and psychopharmacology. Eur J Pharmacol 2003; 463:145-161.

-87 Spritzer MD, Weinberg A, Viau V, Galea LA: Prior sexual experience increases hippocampal cell proliferation and decreases risk assessment behavior in response to acute predator odor stress in the male rat. Behav Brain Res 2009;200:106-112.

88 Cunningham RL, McGinnis MY: Prepubertal social subjugation and anabolic androgenic steroid-induced aggression in male rats. J Neuroendocrinol 2008;20:997-1005.

-89 Edinger KL, Frye CA: Intrahippocampal administration of an androgen receptor antagonist, flutamide, can increase anxiety-like behavior in intact and DHT-replaced male rats. Horm Behav 2006;50:216-222.

90 Fernandez-Guasti A, Martinez-Mota L: Anxiolytic-like actions of testosterone in the burying behavior test: role of androgen and GABA-benzodiazepine receptors. Psychoneuroendocrinology 2005;30:762-770.

91 Miyamoto J, Matsumoto T, Shiina H, Inoue K, Takada I, Ito S, Itoh J, Minematsu T, Sato T, Yanase T, Nawata H, Osamura YR, Kato S: The pituitary function of androgen receptor constitutes a glucocorticoid production circuit. Mol Cell Biol 2007;27:4807-4814.

$>92$ Seale JV, Wood SA, Atkinson HC, Lightman SL, Harbuz MS: Organizational role for testosterone and estrogen on adult hypothalamic-pituitary-adrenal axis activity in the male rat. Endocrinology 2005;146:19731982.

93 McCormick CM, Mahoney E: Persistent effects of prenatal, neonatal, or adult treatment with flutamide on the hypothalamic-pituitary-adrenal stress response of adult male rats. Horm Behav 1999;35:90-101.

94 Bingham B, Gray M, Sun T, Viau V: Postnatal blockade of androgen receptors or aromatase impair the expression of stress hypothalamic-pituitary-adrenal axis habituation in adult male rats. Psychoneuroendocrinology 2011;36:249-257.

$\checkmark 95$ Zuloaga DG, Morris JA, Jordan CL, Breedlove SM: Mice with the testicular feminization mutation demonstrate a role for androgen receptors in the regulation of anxietyrelated behaviors and the hypothalamicpituitary-adrenal axis. Horm Behav 2008;54: 758-766.

96 Rizk A, Robertson J, Raber J: Behavioral performance of $\mathrm{tfm}$ mice supports the beneficial role of androgen receptors in spatial learning and memory. Brain Res 2005; 1034:132-138.

97 Garcia-Falgueras A, Pinos H, Collado P, Pasaro E, Fernandez R, Jordan CL, Segovia S, Guillamon A: The role of the androgen receptor in CNS masculinization. Brain Res 2005; 1035:13-23.

98 Lynch CS, Story AJ: Dihydrotestosterone and estrogen regulation of rat brain androgen-receptor immunoreactivity. Physiol Behav 2000;69:445-453. 
99 Fernandes SA, Gomes GR, Siu ER, DamasSouza DM, Bruni-Cardoso A, Augusto TM, Lazari MF, Carvalho HF, Porto CS: The anti-oestrogen fulvestrant (ICI 182,780) reduces the androgen receptor expression, ERK1/2 phosphorylation and cell proliferation in the rat ventral prostate. Int J Androl 2011;34:486-500.

$>100$ Wersinger SR, Sannen K, Villalba C, Lubahn DB, Rissman EF, De Vries GJ: Masculine sexual lbehavior is disrupted in male and female mice lacking a functional estrogen receptor a gene. Horm Behav 1997;32: $176-183$.

101 Ogawa S, Lubahn DB, Korach KS, Pfaff DW: Behavioral effects of estrogen receptor gene disruption in male mice. Proc Natl Acad Sci USA 1997;94:1476-1481.

102 Ogawa S, Washburn TF, Taylor J, Lubahn DB, Korach KS, Pfaff DW: modifications of testosterone-dependent behaviors by estrogen receptor-a gene disruption in male mice. Endocrinology 1998;139:5058-5069.

103 Ogawa S, Chan J, Chester AE, Gustafsson JA, Korach KS, Pfaff DW: Survival of reproductive behaviors in estrogen receptor beta gene-deficient (betaERKO) male and female mice. Proc Natl Acad Sci USA 1999; 96:12887-12892.

104 Van de Velde P, Nique F, Bouchoux F, Bremaud J, Hameau MC, Lucas D, Moratille C, Viet S, Philibert D, Teutsch G: RU 58,668, a new pure antiestrogen inducing a regression of human mammary carcinoma implanted in nude mice. J Steroid Biochem Mol Biol 1994;48:187-196.

105 Wakeling AE, Bowler J: ICI 182,780, a new antiestrogen with clinical potential. J Steroid Biochem Mol Biol 1992;43:173-177.
06 Vagell ME, McGinnis MY: Inhibition of brain oestrogen receptors by RU 58668. J Neuroendocrinology 1997;9:797-800.

107 Wade GN, Blaustein JD, Gray JM, Meredith JM: ICI 182,780: a pure antiestrogen that effects behaviors and energy balance in rats without acting on the brain. Am J Physiol 1993;265:R1392-R1398.

108 Roy EJ, Wade GN: Binding of [3-H]estradiol by brain cell nuclei and female rat sexual behavior: inhibition by antiestrogens. Brain Res 1977;126:73-87.

109 Sun J, Huang YR, Harrington WR, Sheng S, Katzenellenbogen JA, Katzenellenbogen BS: Antagonists selective for estrogen receptor alpha. Endocrinology 2002;143:941947.

110 Compton DR, Sheng S, Carlson KE, Rebacz NA, Lee IY, Katzenellenbogen BS, Katzenellenbogen JA: Pyrazolo[1,5-a]pyrimidines: estrogen receptor ligands possessing estrogen receptor beta antagonist activity. J Med Chem 2004;47:5872-5893.

111 Alexandre C, Balthazart J: Effects of metabolism inhibitors, antiestrogens and antiandrogens on the androgen and estrogen induced sexual behavior in Japanese quail. Physiol Behav 1986;38:581-591.

112 Adkins EK, Nock BL: The effects of the antiestrogen CI- 628 on sexual behavior activated by androgen or estrogen in quail. Horm Behav 1976;7:417-429.

113 Schlinger BA, Callard GV: Aromatization mediates aggressive behavior in quail. Gen Comp Endocrinol 1990;79:39-53.

114 Beyer C, Morali G, Naftolin F, Larsson K, Perez-Palacios: Effect of some antiestrogens and aromatase inhibitors on androgen induced sexual behavior in castrated male rats. Horm Behav 1976;7:353-363.

115 Clark CR, Nowell NW: The effect of the antiestrogen CI- 628 on androgen-induced aggressive behavior in castrated male mice. Horm Behav 1979;12:205-210.
16 Whalen RE, Battie C, Luttge WG: Anti-estrogen inhibition of androgen induced sexual receptivity in rats. Behav Biol 1972;7: 311-320.

117 Krey LC, McGinnis MY: Time courses of the appearance/disappearance of nuclear androgen+receptor complexes in the brain and adenohypophysis following testosterone administration/withdrawal to castrated male rats: relationships with gonadotropin secretion. J Steroid Biochem 1990;35: 403-408.

118 McGinnis MY, Mirth MC, Zebrowski AF, Dreifuss RM: Critical exposure time for androgen activation of male sexual behavior in rats. Physiol Behav 1989;46:159-165.

119 McGinnis MY, Krey LC, MacLusky NJ, McEwen BS: Steroid receptor levels in intact and ovariectomized estrogen-treated rats an examination of quantitative, temporal and endocrine factors influencing the efficacy of an estradiol stimulus. Neuroendocrinology 1981;33:158-165.

120 Rosenblatt JS, Aronson LR: The decline of sexual behavior in male cats after castration with special reference to the role of prior sexual experience. Behaviour 1958;12: 285-338.

121 Harman SM, Metter EJ, Tobin JD, Pearson J, Blackman MR: Longitudinal effects of aging on serum total and free testosterone levels in healthy men. Baltimore Longitudinal Study of Aging. J Clin Endocrinol Metab 2001;86:724-731.

122 Oberlander JG, Penatti CAA, Porter DM Henderson LP: The buzz about anabolic androgenic steroids: electrophysiological effects in excitable tissues. Neuroendocrinology 2012;96:141-151. 